DOI: https://doi.org/10.15407/techned2018.04 $\leq \underline{079}$

\title{
MATHEMATICAL MODEL AND WORKING REGIMES OF INDUCTION MOTORS OPERATING WITHIN THERMAL POWER STATIONS
}

Journal

Publisher

ISSN

Issue

Pages
Tekhnichna elektrodynamika

Institute of Electrodynamics National Academy of Science of Ukraine 1607-7970 (print), 2218-1903 (online)

No 4, 2018 (July/August)

$79-83$

\section{Authors}

\section{L.I. Mazurenko ${ }^{1 \star}$, K.M. Vasyliv², O.V. Dzhura ${ }^{1 * \star}$}

1 - Institute of Electrodynamics National Academy of Sciences of Ukraine,

pr. Peremohy, 56, Kyiv, 03057, Ukraine,

e-mail:mlins@ied.org.ua

2 - Lviv Polytechnic National university,

S. Bandery, 12, Lviv, 79013, Ukraine

* ORCID ID : http://orcid.org/0000-0002-7059-249X

** ORCID ID : http://orcid.org/0000-0002-0224-3351

\section{Abstract}

A mathematical model of the modes of operation of the asynchronous motor complex for the own requirements of thermal electric power stations in the currents of the phase is developed in the article as well an accent is focused on explicit methods of numerical integration of the differential equations system. A program code was created on its basis as a tool of studying the operating modes of such engines. The investigation of electromagnetic and electromechanical 
processes is carried out. The basic patterns of their transmission in the modes of start-up, stopping, self-launch of asynchronous motors and the regulation of the productivity of the units of their own needs by changing the frequency of rotation of asynchronous motors by changing their number of pairs poles [3, table. 5] are described in the paper. References 8, figures 5.

Key words: mathematical model, numerical methods, asynchronous motor, thermal power station, individual requirements of electric stations, operating modes of asynchronous motors

Received: 05.03.2018

Accepted: 11.04.2018

Published:

\section{References}

1. Abbasov E.M., Golodnov Yu.M., Zilberman V.A, Murzakov A.G. Own needs of thermal power plants. Moskva: Energoatomizdat, 1991. 272 p. (Rus).

2. Syromyatnikov I.A. Modes of operation of asynchronous and synchronous motors. Moskva: Energoatomizdat, 1984. 240 p. (Rus).

3. Matic D., Kanovic Z., Reljic D., Kulic F., Oros D. and Vasic V. Broken bar detection using current analysis - A case study. $20139^{\text {th }}$ IEEE International Symposium on Diagnostics for Electric Machines, Power Electronics and Drives (SDEMPED). Valencia, 2013. Pp. 407-411. DOI:

https://doi.org/10.1109/DEMPED.2013.6645748

4. Zheng F., Sun S., Zhou L., Liu W., Wang J. and Han L. Study on Large Asynchronous Motor Starting Check for Auxiliary Power System. 2010 Asia-Pacific Power and Energy Engineering Conference . Chengdu. 2010. Pp. 1-4. DOI: https:/ /doi.org/10.1109/APPEEC.2010.5448843

5. Almuratova N.K. Energy-saving electric drive of centrifugal pumps: dis. ... Doct. philosophy 
(PhD). Almaty. 2017. 150 p. (Rus).

6. Kopylov I.P. Electric machines: a textbook for students of electromechanics and electricity specialties of universities. Moscow: Vysshaia Shkola. 2006. 607 p. (Rus).

7. Plachtina E.G. Mathematical modeling of electromechanical-ventyl systems. Lviv: Vyshcha shkola. 1986. 164 p. (Rus).

8. Philts R.V. Mathematical Foundations of the Theory of Electromechanical Transformers. Kiev: Naukova dumka, 1979. 208 p. (Rus).

PDF 